\title{
Exploring Servant Leadership Instrument for Social Enterprise (Cooperative)
}

\author{
Aziz Latiff \\ Universiti Malaysia Kelantan (UMK) \\ Izaidin Abdul Majid \\ Universiti Teknikal Malaysia Melaka (UTeM) \\ Maizura Mohamad \\ National Institiute of Entrepreneurship Malaysia (INSKEN)
}

\begin{abstract}
The purpose of this paper is to describe the development and validation of a multi-dimensional instrument to measure servant leadership in social enterprise (cooperative) context. Based on an extensive literature review, expert's judgment and Exploratory Factor Analysis (EFA), 57 items were formulated and only 27 items yielding to five factors: doing right things, develop vision with others, democratic, develop others potential and develop community. The construct develops purposely for social enterprise (cooperative). The participants of the study consisted random sample of the cooperative's manager in Malaysia.
\end{abstract}

Keywords: Exploring Servant Leadership Instrument for Social Enterprise (Cooperative)

\section{Introduction}

The measurements for the leadership attributes specifically for cooperative's perspective were constructed from the literature review in this research. Although a number of scales to measure servant leadership done by researchers, none has designed a questionnaire to measure servant leadership attributes in cooperative organization. As suggested by Russell and Stone (2002), researchers need to examine the genuine of servant leadership characteristics to different types of industries, higher learning, commercial establishment and non-government. To support this gap, the items of servant leadership attributes are constructed according to literature in servant leadership area to fit with social enterprise (cooperative). This study developed a scale to measure servant leadership in social entrepreneurship context. The servant leadership have similarities with cooperative leader's traits or roles. In addition, this research extends studies that need additional contribution and smaller the gap in servant leadership topic. For example, Russel and Stone (2002) and Drury (2004) suggest researchers should examine the genuine of servant leadership characteristics and measure reliability to different types of industries, higher learning, commercial establishment and non-government. According to Prabhu (2008) social entrepreneurial leaders are individuals who make and manage innovative, entrepreneurial organizations or ventures whose primary mission is the social change and growth of their client group. In addition, Lyn Barendsen and Howard Gardener (2004) have proposed social entrepreneur as the new type of leader who can act willingly on their obligations, able to see things positively, regularly evaluate their work, induce pain in their lives are identified as the challenging task and are reformed into a growth oriented opportunities. This leader measure the impact of their activities with business acumen on the society as indicator - the higher their social impact, the greater is their success. The literature in this study related to the attributes of servant leader done from various scholars. Servant leadership characteristics deeply scrutinized in this literature review to develop the instrument to fit with cooperative principles and values. The development and measurement process in this study used Laura and Stephanie (2011) four steps in establishing valid surveys such as defining the construct, item development and judgement, designing and conducting studies to develop a survey and finalizing the instrument. 


\section{Step 1 - Defining the construct}

Defining the construct begins with a thorough exploration of relevant literature in the domain. The literature in this study related to servant leadership attributes or characteristics done by scholars. Since early 1990s through 2013, the work of servant leadership focused on identifying themes and the characteristics to operationalize the concept of servant leadership. The idea and origin of theory of Servant Leadership began in 1970 with the publication of the essay "The Servant as Leader" by Robert Greenleaf. Later, Graham (1991) introduced the inspirational and moral dimensions for the servant leader. Buchen (1998) proposed that self-identity, capacity for reciprocity, relationship building, and preoccupation with the future were essential themes to clarify servant leader attributes. Spears (1998) expanded upon Greenleaf's writings and extracted ten common denominators of significant importance characterizing servant leadership. He emphasized the dimensions of listening, empathy, healing, awareness, persuasion, conceptualization, foresight, stewardship, commitment, and community building. Following, Farling et al. (1999) added the importance of vision, influence credibility, trust and service. While, Laub (1999) put forward valuing people, developing people, building community, display authenticity, providing leadership and sharing leadership. Russell (2001) repeating the elements of vision, credibility, trust, service and added modelling, pioneering, appreciating others and empowerment in contrast with Farling et al. (1999). In addition, Patterson (2003) presented the dimensions of agapáo love, humility, altruism, vision, trust, empowerment, and service as the essential dimensions of servant leadership. Blanchard and Hodges (2003) point out selflessness, integrity, honesty, fearlessness, humility, values-driven behaviour, faith in unconditional love, openness to feedback, a sense of community, self-acceptance, act as visionary role, comprising and act as an implementation role. Dennis and Bocarnea (2005), proposed the same domain from others such as empowerment, love, humility, trust and vision. Barbuto and Wheeler (2006) have measured the construct of altruistic calling, emotional healing, persuasive mapping, wisdom and organizational stewardship. Covey (2006) proposed six criteria such as humility, reverence, openness, ability to teach, respectfulness and caring. Moreover, Liden et al. (2008) developed and measured emotional healing, creating value for community, conceptual skills, empowering, helping subordinate to grow and succeed, putting subordinate first and behave ethically. Sendjya et al. (2008) in their study defined and analyzed the criteria of voluntary subordination, authentic self, covenantal relationship, responsible morality, transcendental spiritually and transforming influence. Reed et al. (2011), proposed new construct of servant leadership related to interpersonal support, building community, altruism, egalitarianism and moral integrity for servant leader manager. van Dierendonck and Nuijten (2011) have measured the construct of empowerment, accountability, standing back, humility, authenticity, courage, interpersonal acceptance and stewardship. Mahembe and Engelbrecht (2013) have developed the servant leadership instrument and test altruistic calling, emotional healing, wisdom, persuasive mapping and organizational stewardship. The summaries of servant leadership attributes shown in table 1.

\begin{tabular}{|l|l|}
\hline SERVANT LEADERSHIP ATTRIBUTES & Honest \\
\hline Greenleaf (1970) & Love \\
& Responsibility \\
\hline Graham (1991) & 1. Inspirational \\
& 2. Moral \\
\hline Buchen (1998) & 1. Self-identity \\
& 2. capacity for reciprocity, \\
& 3. relationship builders, \\
& 4. preoccupation with the future \\
\hline Spears (1998) & 1. Listening, \\
& 2. empathy, \\
& 3. healing, \\
& 4. awareness, \\
& 5. persuasion, \\
& 6. conceptualization, \\
& 7. foresight, \\
& 8. stewardship, \\
& 9. commitment to the growth of people and \\
& 10. building community \\
\hline Farling et al. (1999) & 1. Vision, \\
& 2. influence, \\
& 3. credibility, \\
\hline
\end{tabular}




\begin{tabular}{|c|c|}
\hline & $\begin{array}{l}\text { 4. trust, } \\
\text { 5. service }\end{array}$ \\
\hline Laub (1999) & $\begin{array}{l}\text { Valuing people, } \\
\text { developing people, } \\
\text { displaying authenticity, } \\
\text { offering leadership, } \\
\text { building communities, } \\
\text { sharing leadership }\end{array}$ \\
\hline Page \& Wong (2000) & $\begin{array}{l}\text { 1. Integrity, } \\
\text { 2. humility, } \\
\text { 3. servanthood, } \\
\text { 4. caring for others, } \\
\text { 5. developing for others, } \\
\text { 6. empowering others, } \\
\text { 7. visioning, } \\
\text { 8. goal setting, } \\
\text { 9. leading, } \\
\text { 10. team building, } \\
\text { 11. shared decision making }\end{array}$ \\
\hline Russell \& Stone (2002) & $\begin{array}{l}\text { 1. Vision, } \\
\text { 2. honesty, } \\
\text { 3. integrity, } \\
\text { 4. trust, } \\
\text { 5. service, } \\
\text { 6. modeling, } \\
\text { 7. pioneering, } \\
\text { 8. appreciation of others, } \\
\text { 9. empowerment }\end{array}$ \\
\hline Patterson (2003) & $\begin{array}{l}\text { 1. Agapao love, } \\
\text { 2. humility, } \\
\text { 3. altruism, } \\
\text { 4. vision, } \\
\text { 5. trust, } \\
\text { 6. empowerment, } \\
\text { 7. service }\end{array}$ \\
\hline Blanchard \& Hodges (2003) & $\begin{array}{l}\text { Selflessness, } \\
\text { integrity, } \\
\text { honesty, } \\
\text { fearlessness, } \\
\text { humility, } \\
\text { values-driven behaviour, } \\
\text { faith in unconditional love, } \\
\text { openness to feedback, } \\
\text { a sense of community, } \\
\text { self-acceptance, } \\
\text { act as visionary role - (doing the right thing), } \\
\text { comprising and } \\
\text { an implementation role - (doing things right) }\end{array}$ \\
\hline Dennis \& Bocarnea (2005) & $\begin{array}{l}\text { 1. empowerment, } \\
\text { 2. love, } \\
\text { 3. humility, } \\
\text { 4. trust, and } \\
\text { 5. vision }\end{array}$ \\
\hline Barbuto \& Wheeler (2006) & $\begin{array}{l}\text { 1. Altruistic calling, } \\
\text { 2. emotional healing, } \\
\text { 3. persuasive mapping, } \\
\text { 4. wisdom, } \\
\text { 5. organizational stewardship }\end{array}$ \\
\hline
\end{tabular}




\begin{tabular}{|l|l|}
\hline Covey (2006) & 1. Humility, \\
& 2. reverence, \\
& 3. openness, \\
& 4. ability to teach, \\
& 5. respectfulness, \\
& 6. caring \\
\hline Liden et al. (2008) & 1. Emotional healing, \\
& 2. creating value for community, \\
& 3. conceptual skills, \\
& 4. empowering, \\
& 5. helping subordinates grow and succeed, \\
& 6. putting subordinates first, \\
& 7. behaving ethically \\
\hline Sendjaya, Sarros \& Santora (2008) & 1. Voluntary subordination, \\
& 2. authentic self, \\
& 3. covenantal relationship, \\
& 4. responsible morality, \\
& 5. transcendental spiritually, \\
& 6. transforming influence \\
\hline Reed, Vidaver-Cohen, \& Colwell (2011) & 1. Interpersonal support, \\
& 2. building community, \\
& 3. altruism, \\
& 4. egalitarianism, \\
& 5. moral Integrity \\
\hline
\end{tabular}

\begin{tabular}{|l|l|}
\hline van Dierendonck \& Nuijten (2011) & 1. Empowerment, \\
& 2. accountability, \\
& 3. standing back, \\
& 4. humility, \\
& 5. authenticity, \\
& 6. courage, \\
& 7. interpersonal acceptance \\
& 8. stewardship \\
\hline Mahembe \& Engelbrecht (2013) & Altruistic calling, \\
& emotional healing, \\
& wisdom, \\
& persuasive mapping, \\
& organisational stewardship \\
\hline
\end{tabular}

Table 1: Summary of servant leadership attributes literature

For purpose of this study, seven new dimensions to be validated for a new construct to best fit with social enterprise (cooperative) leadership management. Cooperative organization principles and values seems congruence with servant leadership. Leadership in cooperative is the function to lead the organization on behalf of key stakeholder group - able to formulate the goals through group activity, providing a vision, inspiring, guiding, and listen to both members and the management to achieve the cooperative objectives (Puri, 1979; Parnel, 1995). Thompson et al. (2000) argued even though there are people who are keen to work for their community, but they need leadership qualities and guidance. Thus servant leadership instrument for cooperative organization leadership being develop and measured. The characteristics are categorized according to the similar meaning and most cited criteria among scholars to best fit with cooperative leader. The 
new orientation constructed are i) develop others, ii) demonstrate credibility, iii) develop community, iv) democratic, v) do right things vi) develop vision and vii) deliver for others.

\section{a) Develop others}

Servant leadership promotes the developing of people growth and they have a keen understanding of human characters and embrace a nurturing teaching style that builds self-esteem. The elements of the growth can be started with the interpersonal skills of the leader to benevolently dispose to others. Greenleaf (1970), Dennis and Bocarnea (2005), Page and Wong (2000) and Covey (2006) all contended that servant leader are always caring and love to others. This contention was supported by Spears (1998), Liden et al. (2008), Barbuto and Wheeler (2006), and Mahembe and Engelbrecht (2013). Greenleaf (1970) and Spears (1998) stated that servant leader concern to the follower's emotion by healing it and listen to them. Barbuto and Wheeler (2006) described emotional healing as the ability to recognize the needs and start a healing process for members of the organization. This character can make leader promoting an environment where followers are safe to voice their concerns.

This confirms the work of Spears (1998), Laub (1999), Page and Wong, 2000, and Liden et al. (2008) that servant leader develops and helps their subordinates to grow for success. Table 3. 7 refers to the above servant leadership criteria cited by scholars. These characteristics are derived from the soul of the leader to build positive relationship with others. Crom (1998) pointed out that servant leaders genuinely care for others and are interested in the lives of followers. They can heal or reduce the emotional pain of others, express concern and care and always find ways to develop others. One of the great strengths of servant leadership is the potential for healing one's self and one's relationship with others. This can be started from listening to others in order for the leaders to understand the need of the people. As Maxwell (1998) stated, the effective leaders recognize it takes sincere effort with compassion to reach someone's heart and they must touch other's heart before ask them for a hand.

Ferch and Mitchell (2001) advocated love as a goal for leaders. Greenleaf (1970) added effective leaders are deeply committed to the profession and personal growth of those around them. This statement supported those criteria mentioned above because servant leaders need internal strength and desire to develop others. They must able to allocate time and talent to that purpose. The elements of emotional healing, listening, love, caring for others, commitment to the growth of people, helping subordinate grow and succeed and developing people are interrelated and reasonable to represent as new dimension called develop others. In other words servant leaders develop others by listening, emotional healing, love, caring, and helping subordinate to grow and succeed.

Table 2. 5: Measurement scale referred for dimension of develop others by previous studies

\begin{tabular}{ll}
\hline The Attributes & Authors \\
\hline Healing and & Spears (1998) \\
Emotional healing & Barbuto and Wheeler (2006) \\
& Liden et al. (2008) \\
& Mahembe and Engelbrecht (2013) \\
\hline Listening & Greenleaf (1970) \\
& Spears (1998) \\
\hline Love and & Greenleaf (1970) \\
& Dennis and Bocarnea (2005) \\
Caring for others & Page and Wong (2000) \\
& Covey (2006) \\
\hline Commitment to the growth of people, & Spears (1998) \\
Helping subordinates grow and succeed and & Liden et al. (2008) \\
Developing people & Laub (1999) \\
& Page and Wong (2000) \\
\hline
\end{tabular}

\section{b) Demonstrate credibility}

Kouzes and Posner (1993) mentioned credibility is the essential ingredient in good leadership. It was supported by Ulrich (1996) that credible leaders have personal habits, values, traits and competencies to engender trust and commitment from those who take their direction. Awareness (Spears, 1998), ability to teach (Covey, 2006), wisdom (Barbuto and Wheeler, 
2006; Mahembe and Engelbrecht, 2013), fearlessness (Blanchard and Hodges, 2003), modelling (Russell and Stone, 2002), pioneering (Russell and Stone, 2002) and values-driven behaviour (Blanchard and Hodges, 2003) as mentioned by the scholars can be special values, traits and competencies for servant leader in this study.

According to Barbuto and Wheeler (2006), wisdom is the ability to see and learn from the environment, being able to see how it would affect each member and the organization. This will support (Okpara and Ohn, 2008) which stated that social entrepreneurship leaders must also have traits, which will help them motivate others and lead them in new directions. Thus, this study categorized awareness, ability to teach, wisdom, fearlessness, modeling, pioneering and values-driven behavior characteristics as new dimension called demonstrate credibility as shown in Table 2. 6.

Table 2. 6: Measurement scale referred for dimension of demonstrate credibility by previous studies

\begin{tabular}{ll}
\hline The Attributes & Authors \\
\hline Awareness & Spears (1998) \\
\hline Ability to teach & Covey (2006) \\
\hline Wisdom & Barbuto and Wheeler (2006) \\
& Mahembe and Engelbrecht (2013) \\
\hline Fearlessness & Blanchard and Hodges (2003) \\
\hline Modelling & Russell and Stone (2002) \\
\hline Pioneering & Russell and Stone (2002) \\
\hline Values-driven behavior & Blanchard and Hodges (2003) \\
\hline
\end{tabular}

\section{c) Develop community}

San Juan (2005) emphasized leader must imagine their duty in terms of relationships and community with aim to change and transform. Several researchers mention about concern of the community (Spears, 1998; Laub, 1999; Blanchard and Hodges, 2003; Liden et al., 2008 and Reed et al., 2011). According to Northouse (2007), servant leadership valued everyone's involvement in the community life because it was there that one fully experienced respect, trust, and individual strength. Spears (2010) posited the servant leader senses that much has been lost in recent human history, as a result of the shift from local communities to large institutions as the primary shaper of human lives. This awareness causes the servant leader to seek to identify some means for building community among those who work within a given institution. This study combines these criteria as develop community as these criteria represent the same meaning for servant leader aspiration concerning to community as whole. The summary of this attributes shown in Table 2. 7.

Table 2. 7: Measurement scale referred for dimension of develop community by previous studies

\begin{tabular}{ll}
\hline The Attributes & Authors \\
\hline Building community & Spears (1998) \\
& Laub (1999) \\
& Reed et al., (2011) \\
\hline A sense of community & Blanchard \& Hodges (2003) \\
\hline Creating value for community & Liden et al. (2008) \\
\hline
\end{tabular}

\section{d) Democratic}

According to Bugenhagen (2006), leaders should not acquiring power but must concern themselves with being a soothing presence. Greenleaf (1970) mentioned to be genuine leader they must not afraid to share power and quality performance because "power shared is power multiplied, not lessened". Daft (2005) supported that power is not the primary purpose and aim of the leader. The criteria related to sharing the authority with others and acceptance to others opinion can be interpreted as empowering others (Page and Wong, 2000; Russell and Stone, 2002; Patterson, 2003; Dennis and Bocarnea, 2005; Liden et al., 2008; and van Dierendonck and Nuijten, 2011), openness (Covey, 2006), offering leadership (Laub, 1999), openness to feedback (Blanchard and Hodges, 2003), egalitarianism (Reed et al., 2011), respectfulness and reverence (Covey, 2006) and shared decision making (Page and Wong, 2003). All terms stated above are strongly related 
and comprise the same meaning. Thus, for the purpose of this study, researcher uses term democratic as new dimension of all those characteristics. Refer Table 2. 8.

Table 2. 8: Measurement scale referred for dimension of democratic by previous studies

\begin{tabular}{ll}
\hline The Attributes & Authors \\
\hline Empowering others /empowerment & Page and Wong (2000) \\
& Russell and Stone (2002) \\
& Patterson (2003) \\
& Dennis and Bocarnea (2005) \\
& Liden et al. (2008) \\
& van Dierendonck and Nuijten (2011) \\
\hline Openness & Covey (2006) \\
\hline Offering leadership & Laub (1999) \\
\hline Openness to feedback & Blanchard and Hodges (2003) \\
\hline Egalitarianism & Reed, et al., (2011) \\
\hline Respectfulness and Reverence & Covey (2006) \\
\hline Shared decision making & Page and Wong (2000) \\
\hline
\end{tabular}

\section{e) Do Right Things}

San Juan (2005) claimed servant leadership imbues relational power with a stature of integrity and strength of character. Nakai (2005) addressed that this leader if lead with integrity, common sense, accountability, respect and compassion, more people will get on board. Both honesty and integrity are integral parts of good leadership (Covey, 1996; Fairholm, 1998; Northouse, 1997 and Winston, 1999). Integrity closely related to ethical (Ker, 1998) and Shaw (1997) supported that leader must practice integrity to build trust. In essence, what people want and what organization needs are leaders with integrity who also have the courage to be honest in the face of challenging and potentially self-damaging circumstances.

Another element that creates to do right things is trust. According to Martin (1998) trust is the root of all great leadership. It is also supported by Mayer et al. (1995) that trust is willingness of a party to be vulnerable to the actions of other party based on expectation that the other will perform a particular action important to the trustor, irrespective of the ability to monitor or control other party. Many scholars agree that trust is the most significant factors influencing leader-member relationship, leader effectiveness and enhance productivity (Bennis, 1997; Bennis and Nanus, 1997; Covey, 1990; De Pree, 1997; Fairholm, 1994, 1997, 1998; Martin, 1998; and Ryan and Oestreich, 1998). Servant leadership study by scholars also mentioned about the importance of being ethical and moral. De Pree (2002) posits that without moral purpose, competence has no measure, and trust has no goal. This study highlighted the most attributes in servant leader that are interrelated to guide leader to do right things. They are accountable (van Dierendonck and Nuijten, 2011), authenticity (Laub, 1999; Sendjaya et al., 2008 and van Dierendonck and Nuijten, 2011), integrity (Page and Wong, 2000; Russell and Stone, 2002; Blanchard and Hodges, 2003 and Reed et al. 2011), responsible morality (Sendjaya et al., 2008), behaving ethically (Liden et al., 2008), trust (Farling et al., 1999; Russell and Stone, 2002; Patterson, 2003 and Dennis and Bocarnea, 2005 and honest (Greenleaf, 1970; Blanchard and Hodges, 2003 and Russell and Stone, 2002). Table 2. 9 shows the construct of Do right things.

Table 2. 9: Measurement scale referred for dimension of do right things by previous studies

\begin{tabular}{ll}
\hline The Attributes & Authors \\
\hline Accountability & Van Dierendonck and Nuijten (2011) \\
\hline Authenticity & Laub (1999) \\
& Sendjaya, Sarros and Santora (2008) \\
& van Dierendonck and Nuijten (2011) \\
\hline
\end{tabular}




\begin{tabular}{ll}
\hline Integrity & Page and Wong (2000) \\
& Russell and Stone (2002) \\
& Blanchard and Hodges (2003) \\
& Reed et al. (2011) \\
\hline Responsible morality & Sendjaya et al. (2008) \\
\hline Behaving ethically & Liden et al. (2008) \\
\hline Trust & Farling et al. (1999) \\
& Russell and Stone (2002) \\
& Patterson (2003) \\
& Dennis and Bocarnea (2005) \\
\hline Honest & Greenleaf (1970) \\
& Blanchard and Hodges (2003) \\
& Russell and Stone (2002) \\
\hline
\end{tabular}

\section{f) Develop vision}

Vision unites organizational members and inspires greatness (Miller, 1995). Greenleaf used term foresight and conceptualizing to describe vision. Developing vision for future helps facilitate organizational change and transform action (Miles, 1997). Reinke (2004) defines vision as the degree to which leaders plan and anticipates for future needs, develop concrete mission or vision statements, and keep situations and problems in perspective with the combination of conceptualization and foresight. Both are strongly related. A number of scholars in servant leadership suggested vision as important attributes for servant leadership (Farling et al., 1999; Russell and Stone, 2002; Patterson, 2003; Blanchard and Hodges, 2003; Dennis and Bocarnea, 2005 and Page and Wong, 2000), conceptualization (Spears, 1998 and Liden et al., 2008), goal setting (Page and Wong, 2000) and foresight (Spears, 1998). These attributes can be grouped as develop vision for servant leaders. Refer Table 2. 10.

Table 2. 10: Measurement scale referred for dimension of develop vision by previous studies

\begin{tabular}{ll}
\hline The Attributes & Authors \\
\hline Vision & Farling et al. (1999) \\
& Russell and Stone (2002) \\
& Patterson (2003) \\
& Dennis and Bocarnea (2005) \\
& Page and Wong (2000) \\
\hline Conceptualization & Blanchard and Hodges (2003) \\
Conceptual skills & Spears (1998) \\
\hline Goal setting & Liden et al. (2008) \\
\hline Foresight & Page and Wong (2000) \\
\hline
\end{tabular}

\section{g) Deliver for others}

Greenleaf (1972) described stewardship as holding something in trust for one another. Servant leaders, like stewards, are committed to serving the needs of others and emphasize the use of openness and persuasion, rather than control. Reinke (2004) clarified stewardship as the degree to which leaders put the needs of others and the organization before their own personal needs, use a participatory leadership style, and are committed to the growth of employees and the organization. While Bagget (1997) mentioned first and foremost, a good leader serves others. Service is the core of servant leadership (Block, 1993; De Pree, 1997; Fairholm, 1997, 1998, and Greenleaf, 1977). Fairholm (1997) added that leaders prepare others to embrace a service orientation when they model service through their own actions.

Service attributes were mentioned by (Farling et al., 1999; Russell and Stone, 2002; and Patterson (2003). Putting subordinates first (Liden et al., 2008), voluntary subordination (Sendjaya et al., 2008), Implementation role (Blanchard and Hodges, 2003), stewardship/organizational stewardship (Barbuto and Wheeler, 2006; Mahambe and Engelbrecht, 2013; 
Spears, 1998; and van Dierendonck and Nuijten, 2011). Then, servanthood (Page and Wong, 2000); altruism and altruistic calling (Patterson, 2003; Barbuto and Wheeler, 2006; Reed et al., 2011 and Mahembe and Engelbrecht, 2013); humility (Page and Wong, 2000; Patterson, 2003; Blanchard and Hodges, 2003; Dennis and Bocarnea, 2005; Covey, 2006; and van Dierendonck and Nuijten, 2011). For the purpose of this study, it is called Deliver for others as servant leadership aim is to serve others. The summaries of criteria are shown in Table 2. 11.

Table 2. 11: Measurement scale referred for dimension of deliver for others by previous studies

\begin{tabular}{ll}
\hline The Attributes & Authors \\
\hline Service & Farling et al. (1999) \\
& Russell and Stone (2002) \\
& Patterson (2003) \\
\hline Putting subordinates first & Liden et al. (2008) \\
\hline Voluntary subordination & Sendjaya et al., (2008) \\
\hline Implementation role & Blanchard and Hodges (2003) \\
\hline Organizational stewardship & Barbuto and Wheeler (2006) \\
& Mahembe and Engelbrecht (2013) \\
\hline Servanthood & Page and Wong (2000) \\
\hline Stewardship & Spears (1998) \\
& van Dierendonck and Nuijten (2011) \\
\hline Altruism & Patterson (2003) \\
& Reed et al., (2011) \\
\hline Altruistic calling & Barbuto and Wheeler (2006) \\
& Mahembe and Engelbrecht (2013) \\
\hline Humility & Page and Wong (2000) \\
& Patterson (2003) \\
& Blanchard and Hodges (2003) \\
& Dennis and Bocarnea (2005) \\
& Covey (2006) \\
& van Dierendonck and Nuijten (2011)
\end{tabular}

\section{Step 2 - Instrument development process}

Seven-point rating scale was used in the questionnaire of this study. The reason of using this scale is it was applied by many researchers in survey research (Davis et al., 1989; Moon and Kim, 2001; Venkatesh and Davis, 2000). In addition, it is also more capable than others point-scale, as it allows greater discrimination and finer differences between people (De Vaus, 2002). Furthermore, respondents' take less time, and easy to answer (McCelland, 1994; Churchill, 1995; Frazer and Lawley, 2000). Cox (1980) recommended that the scale points between five and nine should be used, depending on the particular circumstances. According to Miller (1956), in human brain physiology, human brain has a span of apprehension capable of distinguishing about seven (plus minus two) different items. With a strong clarifications and judgment on pointrating scale, a seven-point Likert scale was adopted in this research based on its popularity, high reliability, and appropriateness.

Before conducting the pilot test, the decision from experts and practitioners' review were used to guide the construction of the instrument items in this study. Face validity is scale content logically appears to reflect what was intended to be measured (Zikmund et al., 2013). Researcher appointed two officers from Malaysian Cooperative Commissions as an expert in this study to review and comment the list of questions in terms of jargon, level of understanding and language used. After the officer validated the items, researcher reviewed the highlighted items to be corrected. The items with distracting or confusing language and grammar were eliminated. Approximately 10 to 20 of the initial items were rewritten and/or edited prior to continuing the process.

\section{Step 3 - Designing and conducting studies to develop a survey}


Participants

For the purpose of the pilot survey, 260 participated in this study during the course at Malaysian Cooperative Commissions. According to Baker (1994), a sample of pilot study can be $10 \%$ to $20 \%$ from actual sample size of the study. As discussed earlier, the actual sample size for this research is 370 . For purpose of pilot test, this study used 260 respondents and this number met the required sample size needed.

The strategy of distributing the questionnaires was at MKM during cooperative training and seminar program. Second approach to generate more questionnaire, researcher emailed the questionnaire to the selected sample. The unit of analysis was individual. The subjects were either board of cooperative members or the top level managers of cooperative. They were selected because of their involvement in regards to their participation, operation and their knowledge of the cooperative. In other words, the sample of this study is the representative person from the top management of cooperatives.

This study used the literature on servant leadership as discuss earlier to build set of attributes item, gathered experts to review the questions, added and deleted the item to fit the study requirement. The procedures referred to Laura and Stephanie (2011) steps. The questionnaire was sent to a pool of participants (members of cooperative) database and conducted factor analysis with correlation matrices and scale reliability test to help determine which item to keep for each construct.

\section{Step 4 - Finalizing the scale}

Result - Factor analysis and discussion

In testing the servant leadership attributes, the factorability of the inter-correlation matrix was measured by two tests: KaiserMeyer-Olkin test of Sampling Adequacy (KMO) and Bartlett's Test of Sphericity. KMO measures of sampling adequacy was 0.93 , above the recommended value of 0.60 , and Bartlett's test was $x^{2}=8350.69, p=0.000$, thus, the factor analysis can be conducted. The construct validity of the servant leadership attributes questionnaire was examined through Exploratory Factor Analysis (EFA). The result of Varimax with Kaiser Normalization was a rotated component matrix and extracted 5 factors with eigenvalue greater than 1. 0 . Exploratory factor analysis indicated that the first factor consisted of 9 items. The second factor consisted of 4 items. Factor three consisted of 6 items. Factor four consisted of 5 items and factor five consisted 3 items as shown in Table 4.4 (see Appendix G). The total number of items was 27. Finally, the factors are grouped according to the code - "5D's" a) Do right things, d) Develop vision, c) Democratic, d) Develop others and e) Develop community.

Following, Table 4. 5 indicates the mean and standard deviation and alpha a of all items for servant leadership attributes. All items had mean value more than 5. 0 .

Table 4. 5: Descriptive statistics of servant leadership

\begin{tabular}{|c|c|c|c|c|}
\hline Item & Description & M & SD & a \\
\hline DT34 & Promotes transparency in the cooperative. & 5.53 & 0.94 & \\
\hline DT43 & Honest in all aspects of work or cooperative transactions. & 5.64 & 1. 08 & \\
\hline DT44 & Refuses to use manipulation or deceit to achieve personal goals. & 5.77 & 0.99 & \\
\hline DT45 & Enhances members or employees' trust. & 5.72 & 0.95 & \\
\hline DT53 & Humble to consult others in any situation & 5.43 & 1. 09 & .93 \\
\hline DT54 & Does not centre attention on his or her own accomplishments. & 5. 34 & 1. 06 & \\
\hline DT55 & Hold responsible for the work they carry out. & 5. 38 & 0.98 & \\
\hline DT56 & Emphasizes the importance of focusing on the good of the whole. & 5. 22 & 1. 01 & \\
\hline DT57 & Places interests of members above self-interest. & 5. 46 & 1. 01 & \\
\hline DV13 & Encourages members to dream "big dreams" about the cooperative. & 5.60 & 0.99 & \\
\hline DV14 & Tries to grab as many opportunities for cooperative's success. & 5.66 & 0.90 & \\
\hline DV15 & Effectively thinks through complex problems. & 5. 65 & 0.94 & .88 \\
\hline
\end{tabular}




\begin{tabular}{llll} 
DV18 & Prepare cooperative management to make a positive difference in the future. & 5.60 & 0.90 \\
\hline DM26 & $\begin{array}{l}\text { Enables members or employees to solve problems by themselves instead of just telling them } \\
\text { what to do. }\end{array}$ & 5.23 & 0.96 \\
DM27 & Entrusts members or employees to make decisions which make work easier for them. & 5.23 & 0.95 \\
DM28 & Open about his/her limitations and weaknesses. & 5.33 & 0.86 \\
DM47 & Encourages open exchange of information throughout the cooperative. & 5.30 & 1.00 \\
DM51 & Invites constructive criticism during discussion. & 5.57 & 0.94 \\
DM52 & Encourages members to come up with new ideas. & 5.43 & 0.99 \\
\hline D03 & Takes time to talk to members or employees on a personal level. & 5.27 & 0.93 \\
D05 & Looks for ways to make members or employees successful. & 5.39 & 1.00 \\
D06 & Nurtures members or employees' leadership potential. & 5.43 & 1.03 \\
D07 & Encourages members or employees to enhance their personal skills. & 5.62 & 0.98 \\
D08 & Demonstrates concern for members or employees' personal well-being. & 5.56 & 1.09 \\
\hline DC19 & Inspires others to lead through service for community. & 5.44 & 0.99 \\
DC22 & Encourages members to have a community spirit in the cooperative. & 5.28 & 0.98 \\
DC23 & Emphasizes the societal responsibility of cooperative business activity. & 5.27 & 1.02 \\
\hline
\end{tabular}

\section{Appendix G:Table 4. 4 Rotated components and loadings - servant leadership attributes}

\begin{tabular}{|c|c|c|}
\hline Code & Item & Factor \\
\hline & Construct 1 - DT & Factor 1 \\
\hline Q34 & $\begin{array}{l}\text { Promotes transparency in the } \\
\text { cooperative. }\end{array}$ & 0.62 \\
\hline Q43 & $\begin{array}{l}\text { Honest in all aspects of work or } \\
\text { cooperative transactions. }\end{array}$ & 0.73 \\
\hline Q44 & $\begin{array}{l}\text { Refuses to use manipulation or } \\
\text { deceit to achieve personal goals. }\end{array}$ & 0.71 \\
\hline Q45 & $\begin{array}{l}\text { Enhances members or } \\
\text { employees' trust. }\end{array}$ & 0.65 \\
\hline Q53 & $\begin{array}{l}\text { Humble to consult others in any } \\
\text { situation }\end{array}$ & 0.69 \\
\hline Q54 & $\begin{array}{l}\text { Does not centre attention on his } \\
\text { or her own accomplishments. }\end{array}$ & 0.72 \\
\hline Q55 & $\begin{array}{l}\text { Hold responsible for the work } \\
\text { they carry out. }\end{array}$ & 0.73 \\
\hline Q56 & $\begin{array}{l}\text { Emphasizes the importance of } \\
\text { focusing on the good of the } \\
\text { whole. }\end{array}$ & 0.71 \\
\hline Q57 & $\begin{array}{l}\text { Places interests of members } \\
\text { above self-interest. }\end{array}$ & 0.68 \\
\hline & Construct 2 - DV & Factor 2 \\
\hline Q13 & $\begin{array}{l}\text { Encourages members to dream } \\
\text { "big dreams" about the } \\
\text { cooperative. }\end{array}$ & 0.64 \\
\hline
\end{tabular}




\begin{tabular}{|c|c|c|c|c|}
\hline Q14 & $\begin{array}{l}\text { Tries to grab as many } \\
\text { opportunities for cooperative's } \\
\text { success. }\end{array}$ & 0.69 & & \\
\hline Q15 & $\begin{array}{l}\text { Effectively thinks through } \\
\text { complex problems. }\end{array}$ & 0.72 & & \\
\hline Q18 & $\begin{array}{l}\text { Prepare cooperative } \\
\text { management to make a positive } \\
\text { difference in the future. }\end{array}$ & 0.64 & & \\
\hline & Construct 3 - DM & & Factor 3 & \\
\hline Q26 & $\begin{array}{l}\text { Enables members or employees } \\
\text { to solve problems by themselves } \\
\text { instead of just telling them what } \\
\text { to do. }\end{array}$ & & 0.61 & \\
\hline Q27 & $\begin{array}{l}\text { Entrusts members or employees } \\
\text { to make decisions which make } \\
\text { work easier for them. }\end{array}$ & & 0.63 & \\
\hline Q28 & $\begin{array}{l}\text { Open about his/her limitations } \\
\text { and weaknesses. }\end{array}$ & & 0.62 & \\
\hline Q47 & $\begin{array}{l}\text { Encourages open exchange of } \\
\text { information throughout the } \\
\text { cooperative. }\end{array}$ & & 0.60 & \\
\hline Q51 & $\begin{array}{l}\text { Invites constructive criticism } \\
\text { during discussion. }\end{array}$ & & 0.61 & \\
\hline Q52 & $\begin{array}{l}\text { Encourages members to come } \\
\text { up with new ideas. }\end{array}$ & & 0.67 & \\
\hline & Construct 4 - DO & & & Factor 4 \\
\hline Q3 & $\begin{array}{l}\text { Takes time to talk to members or } \\
\text { employees on a personal level. }\end{array}$ & & & 0.70 \\
\hline Q5 & $\begin{array}{l}\text { Looks for ways to make } \\
\text { members or employees } \\
\text { successful. }\end{array}$ & & & 0.71 \\
\hline Q6 & $\begin{array}{l}\text { Nurtures members or employees' } \\
\text { leadership potential. }\end{array}$ & & & 0.66 \\
\hline Q7 & $\begin{array}{l}\text { Encourages members or } \\
\text { employees to enhance their } \\
\text { personal skills. }\end{array}$ & & & 0.66 \\
\hline \multirow[t]{2}{*}{ Q8 } & $\begin{array}{l}\text { Demonstrates concern for } \\
\text { members or employees' personal } \\
\text { well-being. }\end{array}$ & & & 0.69 \\
\hline & Construct 5 - DC & & & $\underline{\text { Factor } 5}$ \\
\hline Q19 & $\begin{array}{l}\text { Inspires others to lead through } \\
\text { service for community. }\end{array}$ & & & 0.66 \\
\hline Q22 & $\begin{array}{l}\text { Encourages members to have a } \\
\text { community spirit in the cooperative. }\end{array}$ & & & 0.66 \\
\hline Q23 & $\begin{array}{l}\text { Emphasizes the societal } \\
\text { responsibility of cooperative business }\end{array}$ & & & 0.68 \\
\hline
\end{tabular}


activity.

\section{Conclusion}

As a result to the lack of servant leadership study in social enterprises, this study is to provide empirical findings of servant leadership measurement for social enterprise (cooperative) and to determine the possible attributes of servant leadership that may affect cooperative's performance. It is necessary to clarify exactly the attributes of servant leadership measurement in other study to develop a new construct measurement for this study. Finally, the factors are grouped according to the code - "5D's" a) Do right things, d) Develop vision, c) Democratic, d) Develop others and e) Develop community with 27 number of total items. Two dimensions (Deliver for others and Demonstrate credibility) have been dropped from the dimension due to low factor loadings.

\section{Reference}

[1] F. Arham and N. Muenjohn, "Leadership and Organisational Performance in Malaysian SME's: The mediating role of Entrepreneurial Orientation, "Business and Information 2012, pp. 31-41, 2012.

[2] Antonio Thomas, "The Rise of Social Cooperatives in Italy, "International Journal of Voluntary and Non-profit Organizations, vol. 15 no. 3, pp. 243-263, 2004.

[3] As-Sadeq H. A., and Khoury G. C., "Leadership styles in the Palestinian large-scale industrial enterprise, " Journal of Management Development, vol. 25 no. 9, pp. 832-849, 2006.

[4] Banishree Das, Nirod Kumar Palai and Kumar Das, "Problems and Prospectus of the Cooperative Movement in India under The Globalization Regime, " International Economic History Congress XIV, Helsinki 2006, Session 72, 2006.

[5] Barbuto, J. E., and Wheeler, D. W, "Scale development and construct clarification of servant leadership, " Group \& Organization Management, vol. 31 no. 3, pp. 300-326, 2006.

[6] Bidin, Y. H., "Positioning Knowledge Management as Key Success Factor In The Growth of Cooperatives In Malaysia, "Asian Academy of Management Journal, vol. 12 no. 1, pp. 69-82, 2007.

[7] Blanchard, K. H. and Hodges, P., "The Servant Leader: Transforming Your Heart, Head, Hands and Habits," Nashville, TN: J. Countryman, 2003.

[8] Brewer, C., "Servant Leadership: A Review of Literature, " Online Journal of Workforce Education and Development, vol. 4 no 2, pp. 1-8, 2010.

[9] Chaves, R., and Sajardo-Moreno, A., "Social Economy Managers: Between Values and Entrenchment, " Annals of Public and Cooperative Economics, vol. 75 no. 1, pp. 139-161, 2004. doi:10. 1111/j. 1467-8292. 2004. 00246. $x$.

[10] Chibanda, M., Ortmann, G. F., and Lyne, M. C., "Institutional and governance factors influencing the performance of selected smallholder agricultural cooperatives in KwaZulu-Natal, "Agrekon, vol. 48 no. 3, pp. 293-315. 2009. doi:10. 1080/03031853. 2009. 9523828.

[11] CIRIEC, "The Enterprises and Organizations of the Third Systems: A Strategic Challenge For Employment, " International Centre of Research and Information on the Public and Cooperative Economy, 2000. Retrieved January 16, 2012. from http://www. ciriec. ulg. ac. be/fr/telechargements/RESEARCH_REPORTS/dgv_ciriec_fulltext_english. pdf

[12] Covey, S. R., "Servant Leadership: Use your voice to serve others, " Leadership Excellence, vol. 23 no. 12, pp. 5-6. 2006.

[13] Covin, J. G., and Slevin, D. P, "A Conceptual Model of Entrepreneurship as Firm Behavior, "Entrepreneurship Theory \& Practice, vol. 16 no. 1, pp. 7-25, 1991.

[14] Cuevas, C. E., and Fischer, K. P., "Cooperative Financial Institutions, " The World Bank, 2006. doi:10. 1596/978-0-8213-6684-4.

[15] Cox, A., and Healey, J., "Promises to the poor: The record of European development agencies, "Poverty Briefings, Overseas Development Institute, London, vol. 1, 1998. 
[16] Daman Prakash, "Professionalization: Key for Good Governance in Cooperatives, " The Cooperator NCUI New Delhi, vol. 42 no. 1, 2003.

[17] Das, B., "Problems and Prospects of the Cooperative Movement in India Under The Globalization Regime", pp. 1-14. 2006.

[18] Davis, J. L., Bell, R. G., Payne, G. T., and Kreiser, P. M., "Entrepreneurial Orientation and Firm Performance: The Moderating Role of Managerial Power, " American Journal of Business, vol. 25 no. 2, pp. 41-54, 2010. doi:10. 1108/19355181201000009.

[19] Dennis, R. S., and Bocarnea, M., "Development of the Servant Leadership Assessment Instrument, " Leadership \& Organization Development Journal, vol. 26 no. 8, pp. 600-615, 2005. doi:10. 1108/01437730510633692.

[20] Ebrashi, R. El., "Social entrepreneurship theory and sustainable social impact, " Social Responsibility Journal, vol. 9 no. 2, pp. 188-209, 2013. doi:10. 1108/SRJ-07-2011-0013

[21] Ericka C., Andreaus M., Carini C., and Carpita M., "Exploring the efficiency of Italian social cooperatives by descriptive and principal component analysis, "Springer-Verlag, vol. 6, pp. 117-136, 2012.

[22] Fauquet, Georges, "The Co-operative Sector, " 1965. (First published in 1935). English translation by Cooperative Union, Manchester, 1951.

[23] Farling, M. L., Stone, A. G., and Winston, B. E., "Servant leadership: Setting the stage for empirical research, " Journal of Leadership Studies, vol. 6 no. 2, pp. 49-72, 1999.

[24] Fulton, M. E., "Cooperatives and Member Commitment, " vol. 8, 1999. http://www. Ita. hse. fi/1999/4/ta_1999_04_a4.pdf

[25] Fulton, M. E., and Hueth, B., "Cooperative Conversions, Failures and Restructurings : An Overview, " pp. 23, 2009.

[26] Ganesh N. Prabhu, "Social entrepreneurial leadership, " Career Development International, vol. 4, no. 3, pp. $140-145,1999$

[27] Greenleaf, R. K., "The servant as a leader, " Indianapolis, IN: Greenleaf Center, 1970.

[28] Greenleaf, R. K., "Servant Leadership". Mahwah, NJ: Paulist Press, 1977.

[29] Greenleaf, R. K., "On becoming a servant-leader, " San Francisco: Josey-Bass Publishers, 1996.

[30] Hernez-Broome, G., and Hughes, L. R., "Leadership development: Past, present, and future, " Journal of Human Resources Planning, vol. 27 no. 1, pp. 24-33, 2004.

[31] Himawan Hariyoga and Richard J. Sexton, "The Rise and Fall of Tri Valley Growers Cooperative, "Journal of Cooperatives, vol 23, pp. 87-100, 2009.

[32] $\mathrm{Hu}$, J., and Liden, R. C., "Antecedents of team potency and team effectiveness: An examination of goal and process clarity and servant leadership, " Journal of Applied Psychology, vol. 96, 2011.

[33] International Cooperative Alliance (ICA), "Statement of the Cooperative Identity, " 1995. http://www. wisc. edu/uwcc/icic/issues/prin/21-coperativeidentity. cent/identity. html.

[34] Indian Cooperative News, (2012). Retrieved online on 21 January 2014 http://indiancooperative. com/lawslegislations/bombay-hcs-order-in-veerashaiva-cooperative-bank-fraud/

[35] International Labour Office Geneva (ILO), "Leadership Training Manual for Women Leaders of Cooperative, " India, 2005. Retrieved February 2014, From http://www. ilo. org/wcmsp5/groups/public/---asia/---ro-bangkok/--sro-new_delhi/documents/publication/wcms_124337. pdf

[36] Joseph, E. E., and Winston, B. E., "A correlation of servant leadership, leader trust, and organizational trust, " Leadership \& Organization Development Journal, vol. 26 no. 1, pp. 6- 22, 2005.

[37] Jennings, D. B., "Those who would lead must first serve: The praxis of servant leadership by public school principals, " Dissertations Abstracts International, 2002. 
[38] Keeling, J. J., and Carter, C. A., "Lessons in Cooperative Failure : The Rice Growers Association Experience, "Working Paper, NCR-194 Research on Cooperatives Annual Meeting, Kansan City, Missouri, November 2-3, 2004.

[39] Keh, H. T., Nguyen, T. T. M., and Ng, H. P., "The effects of entrepreneurial orientation and marketing information on the performance of SME's, Journal of Business Venturing, vol. 22 no. 4, pp. 592-611, 2007. doi:10. 1016/j. jbusvent. 2006. 05. 003.

[40] Kamsi, R., "A good governance of cooperatives, "Coop Dimension, vol. 1, pp. 14-21, 2008.

[41] Kezar, A., "Reconstructing static images of leadership: An application of personality theory, " Journal of Leadership Studies, vol. 8 no. 94, 2002.

[42] Korry, I. N. S., "The Role of Entrepreneurial Orientation in Mediating the Effect of Organizational Culture and Government Policy toward Business Performance (Case Study : Koperasi Unit Desa in Bali Province), " International Journal of Business and Commerce, vol. 2 no. 12, pp. 29-42, 2013. Retrieved from www. ijbcnet. com.

[43] Lasprogata, G. A., and Cotton, M. N., "Contemplating enterprise: The business and legal challenges of social entrepreneurship, " American Business Law Journal, vol. 41, pp. 67-113, 2003.

[44] Laub, J. A., "Assessing the servant organization: Development of the Servant Organizational Leadership Assessment (SOLA) instrument, " Doctoral dissertation, Florida Atlantic University, Boca Raton, 1999.

[45] Leadbeater, C., "The rise of the social entrepreneur, " London: Demos, 1997.

[46] Lees M., and Volkers R., "General trends, findings and recommendations, " Review of International Cooperation, vol. 89 no. 4, pp. 37-49, 1996.

[47] Lees M., "Corporate governance in European co-operatives in The World of Co-operative Enterprise, " Plunkett Foundation, Oxford, 1995.

[48] Liden, R. C., Wayne, S. J., Zhao, H., and Henderson, D., "Servant leadership: Development of a multidimensional measures and multilevel assessment, " Leadership Quarterly, vol. 19, pp. 161-177, 2008.

[49] Ling Y, Lubatkin M. H., Simsek Z., and Veiga J. F., "The Impact of Transformational CEO's on the Performance of Small-to-Medium-Sized Firms: Does Organizational Context Matter?, " Journal of Applied Psychology, vol. 93 no. 4, pp. 923-934, 2008.

[50] Lo M. C., Ramayah T., Hii Wei M., and Songan P., "The relationship between leadership styles and organizational commitment in Malaysia: role of leader-member exchange, " Asia Pacific Business Review, vol. 16 no. 2, pp. 79-103, 2010.

[51] Lumpkin, G. T., and Dess, G. G., "Linking Two Dimensions of Entrepreneurial Orientation to Firm Performance: The Moderating Role of Environment and Industry Life Cycle, "Journal of Business Venturing, vol. 16 no. 5, pp. 429-451, 2001.

[52] Lubin, K. A., "Visionary leader behaviors and their congruency with servant leadership characteristics, " Dissertation Abstracts International, 62 (08), 2645, 2001.

[53] Machethe C., L., "Factors contributing to poor performance of agricultural cooperatives in less developed areas, "Agrekon vol. 29 no. 4, pp. 305-309, 1990.

[54] Mahembe, B., and Engelbrecht, A. S., "A confirmatory factor analytical study of a servant leadership measure in South Africa, "South Africa Journal of Industrial Psychology, vol. 39 no. 2, pp. 1-8, 2013. doi:10. 4102/sajip. v39i2. 1127.

[55] Mair, J., "Social entrepreneurship: taking stock and looking ahead, "World Entrepreneurship Forum, IESE Business School, pp. 1-17, 2008.

[56] Mair, J., \& Martí, I., "Social entrepreneurship research: A source of explanation, prediction, and delight, " Journal of World Business, vol. 41 no. 1, pp. 36-44, 2006. doi:10. 1016/j. jwb. 2005. 09. 002

[57] Mateos-ronco, A., and Mas, Á. L., "Developing a business failure prediction model for cooperatives: Results of an empirical study in Spain, "vol. 5 no. 26, pp. 10565-10576, 2011. 
[58] Mayer, D. M., Bardes, M., and Piccolo, R. F., "Do servant-leaders help satisfy follower needs? An organizational justice perspective, " European Journal of Work and Organizational Psychology, vol. 17, pp. 180-197, 2008.

[59] McDougall, P. P. and Oviatt, B. M., "International Entrepreneurship: The Intersection of Two Research Paths, " Academy of Management Journal, vol. 43 no. 5, pp. 903-906, 2000.

[60] Miller, D., and Friesen, P. H., "Innovation in Conservative and Entrepreneurial Firms: Two Models of Strategic Momentum, "Strategic Management Journal, vol. 3 no. 1, pp. 1-25, 1982.

[61] Miller, D., and Friesen, P. H., "Strategy-making and Environment: The Third Link, "Strategic Management Journal, vol. 4 no. 3, pp, 221-235, 1983.

[62] Mohamad, M., Othman, I. W., and Mohamed, A., "Accountability Issues and Challenges: The Scenario for Malaysian Cooperative Movement, "International Journal of Management Science and Engineering, vol. 7 no. 6, pp. 872-877, 2013.

[63] Mojtahed, D., "Conflict Management of Cooperative Organizations in Contemporary Iran: A Review Analysis. Public Organization Review, "vol. 7 no. 2, pp. 163-180, 2007. doi:10. 1007/s11115-006-0028-6

[64] Moreno A., M., and Casillas J., C., "Entrepreneurial Orientation and Growth of SMEs: A Causal Model, Entrepreneurship Theory and Practice, " vol. 32 no. 3, pp. 507-528, 2008.

[65] Morris, M. H., and Kuratko, D. F., "Corporate entrepreneurship: Entrepreneurial development within organizations, " Orlando, FL: Harcourt College Publishers, 2002.

[66] Neubert, M. J., Kacmar, K. M., Carlson, D. S., Chonko, L. B., and Roberts, J. A., "Regulatory focus as a mediator of the influence of initiating structure and servant leadership on employee behavior, "Journal of Applied Psychology, vol. 93 no. 6, pp. 1220-1233, 2008.

[67] Nkhoma, A. A., and Conforte, D., "Unsustainable cooperatives: lessons from Malawi, " IFAMA Symposium, Frankfurt, pp. 1-9, 2011.

[68] Otito O., and Ogionwo W., "An Introduction to social studies, " Heinemann Educational Books, Nig Plc, 1994.

[69] Page, D., and Wong, T. P., "A conceptual framework for measuring servant-leadership, " In S. (Ed. ), The human factor in shaping the course of history and development, pp. 69-110, Lanham, MD: University Press of America, 2000.

[70] Patterson, K., "Servant leadership: a theoretical model, " Doctoral Dissertation, Graduate School of Business, Regent University, 2003.

[71] Peterson, S., Galvin, B. M., and Lange, D., "CEO servant leadership: Exploring executive characteristics and firm performance, Personnel Psychology, vol. 65, pp. 565-596, 2012.

[72] Prahalad, C. K., "The fortune at the bottom of the pyramid: Eradicating poverty through profits, "Wharton School Publishing, Upper Saddle, NJ, 2005.

[73] Rauch A, Wiklund J, Lumpkin GT and Frese M., "Entrepreneurial Orientation and Business Performance: An Assessment of Past Research and Suggestions for the Future, "Entrepreneurship Theory and Practice, vol. 33 no. 3, pp. 761-787, 2009.

[74] Reed, L. L., Vidaver-Cohen, D., and Colwell, S. R., "A New Scale to Measure Executive Servant Leadership: Development, Analysis, and Implications for Research, "Journal of Business Ethics, vol. 101 no. 3, pp. 415434, 2011.

[75] Russell, R. F., and Stone, A. G., "A review of servant leadership attributes: Developing a practical model. Leadership \& Organization Development Journal, " vol. 23 no. 4, pp. 145-157, 2002.

[76] Robert Cropp., "Cooperative Leadership, "University of Winconsin Centre of Cooperative, Bulletin 9, 2005. Retrieved February 2014, From: http://www. uwcc. wisc. edu/pdf/Bulletins/bulletin_07_05. pdf

[77] Schaubroeck, J., Lam, S. S. K., and Peng, A. C., "Cognition-based and affect-based trust as mediators of leader behavior influences on team performance, "Journal of Applied Psychology, vol. 96, pp. 863-871, 2011.

[78] Sendjaya, S., Sarros, J. C., and Santora, J. C., "Defining and measuring servant leadership behavior in organizations, "Journal of Management Studies, vol. 45 no. 2, pp. 402-424, 2008. 
[79] Sartain, L., "HR from the heart: Inspiring stories and strategies for building the people side of great business, " New York: AMACOM, 2003.

[80] Spears, L. C., "Servant-leadership: The Circle of Responsibilities for Co-ops Board, "Executive Excellence, vol. 15 no. 7, pp. 11, 1998. Retrieved March 02, 2013. from www. rurdev. usda. gov/rbs/pub/cir61. pdf

[81] Spears, R., "Governance in Democratic Member Based Organisations, "Annals of Public and Cooperative Economics vol. 75 no. 1, pp 33-60, 2004.

[82] Skurnik, S., "The Role of Cooperative Entrepreneurship and Firms in Organising Economic Activities - Past, Present and Future, "The Finnish Journal of Business Economics, vol. 1, pp. 103-124, 2002.

[83] Smart, D. T. and Conant, J. S., "Entrepreneurial orientation, distinctive marketing competencies and organization performance, " Journal of Applied Business Research, vol. 10, pp. 28-38, 1994.

[84] Swamy, R., "The making of a social entre-preneur: the case of Baba Amte, "Vikalpa, vol. 15 no. 4, pp. 29-39, 1990.

[85] Thompson, J., Alvy, G., and Lees, A., "Social entrepreneurship - a new look at the people and the potential Social entrepreneurship - A new look at the people and the potential, " Magement Decision, vol. 38 no. 5, pp. 328-338, 2000.

[86] Todorovic W., and Schlosser F., K., "An Entrepreneur and a Leader: A Framework Conceptualizing the Influence of Leadership Style on a Firm's Entrepreneurial Orientation - Performance Relationship, "Journal of Small Business and Entrepreneurship, vol. 20 no. 3, pp. 289-308, 2007.

[87] United States Department of Agriculture (USDA), (1960). Retrieved January 2011, From http://www. rurdev. usda. gov/rbs/pub/jan99/1960s. html

[88] USA Cooperative Information Report, "Cooperative Management, Farmer Cooperative in United States, " United States Department of Agriculture Rural Business-Cooperative Service, vol. 1, pp. 3-32, 1995.

[89] Van Dierendonck, D., and Nuijten I., "Servant leadership: A review and synthesis, "Journal of Management, vol. 37, pp. 1228-1261, 2011.

[90] Vanourek, R. A., "Servant Leadership and the future, " Indianapolis, IN: The Robert K. Greenleaf Centre, 1987.

[91] Van Niekerk J. A. S., "Cooperative theory and practice, " Silverton: Promedia Publications, 1988.

[92] Van der Walt's L., "The resuscitation of the cooperative sector in South Africa, "Paper presented at the International Cooperative Alliance XXI, International Cooperative Research Conference, 11-14 August 2005, Cork, Ireland.

[93] Walumbwa, F. O., Hartnell, C. A., and Oke, A., "Servant leadership, procedural justice climate, service climate, employee attitudes, and organizational citizenship behavior: A cross-level investigation, " Journal of Applied Psychology, vol. 95, pp. 517-529, 2010.

[94] Weihe, T., "Cooperative in Conflict and Failed States, "U. S. Overseas Cooperative Development Council pp. 1-39, 2004. http: www. uwcc. wisc. edu/info/int//weihe. pdf

[95] Wiklund, J., and Shepherd, D., "Entrepreneurial Orientation and Small Business Performance: A Configurationally Approach, "Journal of Business Venturing, vol. 20 no. 1, pp. 71-91, 2005.

[96] Yang C. W., "The Relationships Among Leadership Styles, Entrepreneurial Orientation, and Business Performance, " Managing Global Transitions, vol. 6, pp. 257-27, 2008.

[97] Yukl, G., "Leadership in Organizations, "6th Ed. New Jersey: Prentice-Hall, 2006.

[98] Zamagni, V. N., "Interpreting the Roles and Economic Importance of Cooperative Enterprises in a Historical Perspective, " Journal of Entrepreneurial and Organizational Diversity, vol. 1 no. 1, pp. 21-36, 2012. doi:10. 5947/jeod. 2012. 002 